\title{
OCENA METROLOGICZNA SYSTEMU POMIAROWEGO DLA POTRZEB WYZNACZANIA UDZIALU FAZ W PRZEPLYWIE MIESZANIN GAZ-CIECZ METODĄ TOMOGRAFII POJEMNOŚCIOWEJ 3D
}

\author{
Radoslaw Wajman $^{1}$, Henryk Fidos ${ }^{2}$, Paweł Fiderek ${ }^{1}$, Tomasz Jaworski ${ }^{1}$, Jacek Nowakowski ${ }^{1}$, \\ Dominik Sankowski ${ }^{1}$, Robert Banasiak ${ }^{1}$ \\ ${ }^{1}$ Instytut Informatyki Stosowanej Politechniki Łódzkiej, ${ }^{2}$ Katedra Inżynierii Chemicznej Politechniki Łódzkiej
}

Streszczenie. Przemysłowe systemy diagnostyki i monitorowania potrzebuja nowych narzędzi oferujących możliwości nieinwazyjnej obserwacji i analizy procesów przeplywów dwufazowych mieszanin gaz-ciecz. Opracowany system pomiarowy dedykowany jest dla potrzeb nieinwazyjnego wyznaczania procentowego udzialu faz oraz identyfikacji struktur $w$ przeplywach dwufazowych $w$ rurociagach pionowych i poziomych. Artykut prezentuje wybrane rezultaty prac badawczych, w wyniku, których dokonano oceny własności metrologicznych prototypowego systemu trójwymiarowej tomografii pojemnościowej. Prace badawcze obejmowaty między innymi: zagadnienie optymalizacji struktury czujnika ECT, a także metrologiczna ocene dokładności rekonstrukcji obrazu oraz wyznaczania procentowego udziału faz w porównaniu z innymi metodami. W wyniku przeprowadzonej analizy wykazano duża przydatność systemu 3D ECT do nieinwazyjnego, szybkiego diagnozowania dynamicznych procesów przeplywowych.

Słowa kluczowe: przepływ dwu-fazowy, tomografia pojemnościowa ECT, wizualizacja trójwymiarowa, struktury przepływów, przepływy przemysłowe

\section{METROLOGICAL EVALUATION OF MEASUREMENT SYSTEM FOR TWO-PHASE FLOW FRACTIONS DETERMINATION USING 3D ELECTRICAL CAPACITANCE TOMOGRAPHY}

\begin{abstract}
The industrial diagnostic and monitoring systems require new methods offering the possibility of non-invasive observation and analysis of the two-phase gas-liquid mixtures flows. The designed new measurement system is dedicated for non-invasive percentage phase distribution calculation and flow structure identification in the vertical and horizontal pipelines. This paper presents some research results of the metrological validation of the designed three-dimensional capacitance tomography measurement system including: the 3D ECT sensor structure optimization, the metrological analysis of the image reconstruction process accuracy and the metrological analysis of the results of the phase distribution calculation method in comparison with other common technics. As a result of performed analysis the height capability of the 3D ECT measurement system for non-invasive real time dynamic flow processes identification was proved.
\end{abstract}

Keywords: two-phase flow, capacitance tomography ECT, three-dimensional visualization, flow structures, industrial flows

\section{Wprowadzenie}

W ramach zrealizowanych $\mathrm{w}$ Instytucie Informatyki Stosowanej Politechniki Łódzkiej prac badawczych opracowane zostało narzędzie posiadające możliwości nieinwazyjnego monitorowania i diagnozowania procesów przepływów dwufazowych mieszanin gaz-ciecz, które znajdują szerokie zastosowania w przemyśle budowlanym, spożywczym, farmaceutycznym, chemicznym, rafineryjnym i wielu innych. Opracowany system pomiarowy dedykowany jest do wyznaczania procentowego udziału faz oraz identyfikacji struktur w przepływach dwufazowych w rurociągach pionowych i poziomych [1]. Istota proponowanego rozwiązania polega na zastosowaniu nowatorskiej, trójwymiarowej struktury czujnika pojemnościowego o elektrodach wewnętrznych, systemu pomiarowego elektrycznej tomografii pojemnościowej ECT 3D oraz specjalizowanych algorytmów równoległego, szybkiego przetwarzania danych pomiarowych do wizualizacji wnętrza fragmentu przepływu mieszanin gaz-ciecz.

W artykule opisano rezultaty prac badawczych, w wyniku, których dokonano oceny własności metrologicznych prototypowego systemu trójwymiarowej tomografii pojemnościowej. Prace badawcze obejmowały:

- optymalizację struktury czujnika pojemnościowego dla systemu ECT o przestrzennym rozkładzie elektrod pod kątem możliwości skanowania przepływu mieszanin gazciecz;

- metrologiczna ocenę dokładności procesu rekonstrukcji obrazu na bazie rzeczywistych danych pomiarowych i symulacji;

- metrologiczną ocenę dokładności wyznaczania procentowego udziału faz przepływu mieszanin gaz-ciecz w porównaniu z metodami: szybkozamykających się zaworów oraz identyfikacji struktury przepływu za pomocą kamery CCD.

\section{Optymalizacja struktury czujnika pojemnościowego systemu ECT}

Jednym z kluczowych elementów stanowiska diagnostycznomonitorującego, opartego na systemie 3D ECT, jest czujnik pojemnościowy (określany często jako sonda pojemnościowa). Zbudowanie poprawnej struktury mechaniczno-elektrycznej czujnika pojemnościowego 3D jest zagadnieniem złożonym. Najczęściej rozkład elektrod, ich kształt i wymiary geometryczne, są określane względem użytecznego zakresu wrażliwości pomiarowej tomografu pojemnościowego oraz przewidywanego zakresu stałych elektrycznych badanego medium $[6,10]$.

W skład czujnika 3D dla systemu tomografii pojemnościowej weszły 32 elektrody. Oczywiście większa liczba elektrod, wyznaczająca większą liczbę niezależnych pomiarów, jest teoretycznie bardziej korzystna ze względu na jakość rekonstruowanego obrazu. W praktyce liczba elektrod musi być jednak ograniczona ze względu na określoną czułość urządzeń pomiarowych, która wymaga, aby mierzone wielkości i zmiany pojemności miały wartość - większą od możliwej do zmierzenia wartości minimalnej, co z kolei wymusza stosowanie elektrod z odpowiednio dużym polem aktywnej powierzchni. Dodatkowo, pojemności między elektrodami są redukowane przez ekranowanie układu przed oddziaływaniami zewnętrznymi i kształtujące pole elektryczne w pożądany sposób. Na skutek tych ograniczeń wartości pojemności między elektrodami są bardzo małe, na ogół znacznie mniejsze od $1.0 \mathrm{pF}$ i dodatkowo mierzone wraz $\mathrm{z}$ istniejącymi pojemnościami pasożytniczymi. Są one wnoszone przykładowo przez okablowanie i sprawiają, że bezpośredni pomiar pojemności międzyelektrodowych jest bardzo trudny, obarczony dużym błędem i niepraktyczny. Zamiast tego rozwiązania, powszechnie stosowaną metodą jest pomiar zmian pojemności, w którym bezwzględna wartość mierzonych pojemności jest obarczona dużym błędem, ale różnice pojemności mierzone są już z większą dokładnością. 
Czujnik ECT 3D budowany jest najczęściej na walcowym profilu zamkniętym. Kluczowymi elementami czujnika pojemnościowego, mającymi wpływ na pole elektryczne są: układ elektrod pomiarowych oraz system ekranów. Najczęściej stosuje się ekranowanie zewnętrzne, w postaci płaszcza miedzianego, uziemionego i odizolowanego od systemu elektrod, obejmującego swoim obszarem całą strefę pomiarową czujnika. Zastosowanie ekranu zewnętrznego umożliwia skuteczne odseparowanie układu pomiarowego czujnika od zakłóceń zewnętrznych oraz ograniczenie obszaru i zdolności detekcyjnych czujnika do obszaru profilu zamkniętego oraz jego bliskiego sąsiedztwa. Wyznaczono parametry geometryczno-mechaniczne trzech rodzajów trójwymiarowych czujników pojemnościowych, różniące się średnicą profilu montażowego. Parametry te, to przede wszystkim kształt i powierzchnia elektrod, odstępy międzyelektrodowe, szerokość ekranów wewnątrz-elektrodowych i brzegowych, oraz grubość izolacji ochronnej. Dotychczasowe doświadczenia praktyczne autorów w zakresie przemysłowych zastosowań elektrycznej tomografii procesowej pozwoliło stwierdzić, iż opracowanie analogicznej koncepcji czujników na rury o różnych profilach - dodatkowo, dedykowanych do badania cieczy o różnej wartości przenikalności elektrycznej - nie jest zadaniem polegającym na bezpośrednim „przeskalowaniu” geometrii. Pole elektryczne ma charakter silnie nieliniowy i dobór tych parametrów również musi być realizowany drogą eksperymentalną. Stąd też kluczowym etapem stało się zastosowanie $\mathrm{w}$ ramach badań wysoko precyzyjnego miernika impedancji (Agilent E4980A). W trakcie tych eksperymentów przestrzeń eksperymentalnego prototypu czujnika wypełniana była glikolem (reprezentantem mediów o dużej przenikalności elektrycznej) oraz powietrzem (reprezentantem mediów o małej przenikalności elektrycznej) i wykonywane były statyczne pomiary pojemności przy pomocy wspomnianego miernika.

Analiza działania testowanych $\mathrm{w}$ trakcie przeprowadzonych pomiarów różnych konfiguracji elektrod pozwoliła efektywnie dopasować dyskutowane powyżej parametry czujnika do zakresu pomiarowego stosowanego systemu tomografii pojemnościowej.

Dodatkowo, w ramach prac badawczych przeprowadzono numeryczną analizę rozkładu wrażliwości dla zaprojektowanych nowych struktur trójwymiarowych czujników pojemnościowych z elektrodami wewnętrznymi oraz dla czujników klasycznych $\mathrm{z}$ elektrodami zewnętrznymi - rysunek 1 . Dla potrzeb analizy ich wstępnej przydatności do badań przepływów dwufazowych mieszanin gaz-ciecz, przeprowadzony został proces symulacji komputerowej. Należy tu podkreślić, iż przeprowadzona symulacja efektywnie wspomogła proces optymalnego doboru geometrii czujnika w kryterium rozkładu jego wrażliwości, dla potrzeb badań mieszanin z udziałem cieczy o wysokiej wartości względnej przenikalności elektrycznej. Na podstawie bezpośrednich pomiarów pojemności, uzyskanych przy pomocy miernika RLC oraz symulacji numerycznej, opracowane zostały projekty czujników dla odpowiednich średnic rurociągów. Na tej bazie, opracowano komputerowy model czujnika pojemnościowego, który zastosowano przy wyznaczaniu macierzy wrażliwości.

W przypadku czujnika $\mathrm{z}$ elektrodami zewnętrznymi całkowicie wypełnionego cieczą, uwage zwróciło znikome wnikanie pola $\mathrm{w}$ środek czujnika. Pole elektryczne skupione było głównie na obrzeżach rury wewnętrznej, wykonanej z PMMA Polimetakrylan metylu (Pleksi) - o względnej przenikalności elektrycznej $\left(\varepsilon_{\mathrm{r}}=2.8\right)$ znacznie niższej, niż wartość przenikalności medium wypełniającego przestrzeń czujnika, np. glikolu $\left(\varepsilon_{\mathrm{r}}=37.0\right)$. Takie zjawisko nie występuje $\mathrm{w}$ przypadku opracowanego prototypu czujnika $\mathrm{z}$ elektrodami wewnętrznymi również wypełnionego cieczą. W czujniku $\mathrm{z}$ elektrodami wewnętrznymi pole elektryczne równomiernie rozkłada się w całej przestrzeni czujnika. Z matematyczno-fizycznego punktu widzenia, macierze wrażliwości dla czujników pojemnościowych 3D wyznaczane są bezpośrednio z własności pola elektrycznego [8]. To sprawia, że opisane powyżej zjawisko znikomego wnikania pola elektrycznego w głąb czujnika, charakterystycznego dla czujnika z elektrodami zewnętrznymi, przekłada się nie tylko na macierze wrażliwości i w konsekwencji na proces rekonstrukcji obrazów, ale również i na same pomiary pojemności.

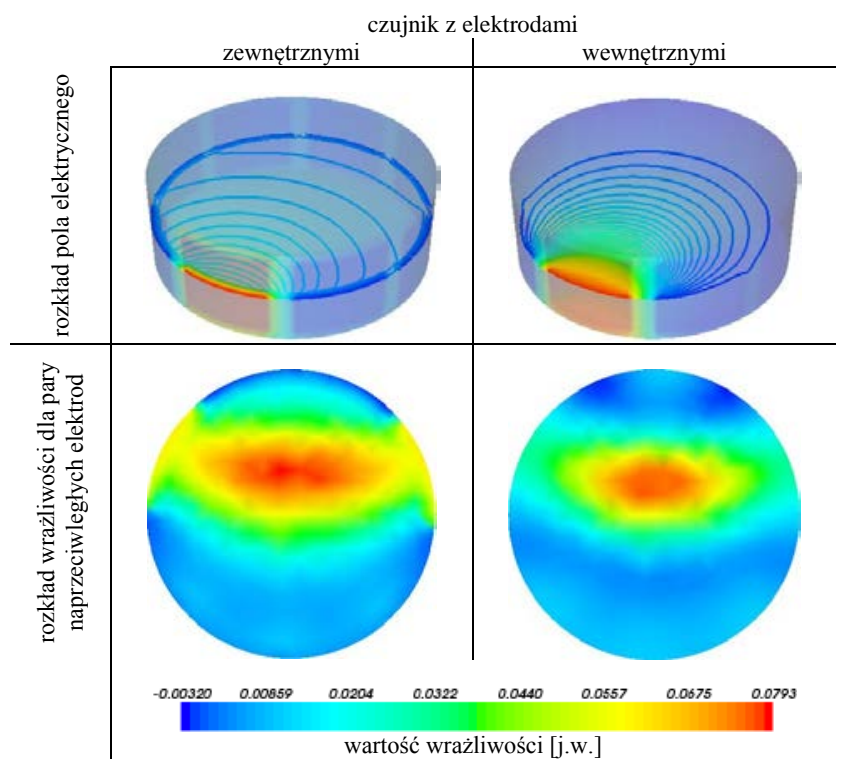

Rys. 1. Przekroje poprzeczne rozkładu pola elektrycznego oraz rozkładu wrażliwości czujników dla pary elektrod naprzeciwlegtych zewnętrznych $i$ wewnętrznych

\section{Ocena dokładności procesu rekonstrukcji obrazu na bazie rzeczywistych danych pomiarowych i symulacji}

Mechanizm budowania obrazu dla potrzeb wizualizacji procesów przemysłowych przy użyciu elektrycznej tomografii pojemnościowej określany jest jako rekonstrukcja (bądź konstrukcja) obrazu. W praktyce proces ten może mieć charakter liniowy lub nieliniowy. W pierwszym przypadku rekonstrukcja obrazu jest wyznaczana bezpośrednio (deterministyczne metody projekcji wstecznej lub techniki regularyzacyjne [12]), bądź też na drodze optymalizacji iteracyjnej przy użyciu stałego symulowanego rozkładu wrażliwości w komputerowym modelu czujnika [2]. W drugim przypadku (rozważanym w ramach niniejszego artykułu) proces przebiega w schemacie iteracyjnym i uwzględnia nieliniowy charakter pola elektrycznego. Nieliniowość można aproksymować poprzez aktualizację modelu wrażliwościowego czujnika w oparciu o poprzednio zrekonstruowane obrazy 3D.

Macierz wrażliwości jest głównym czynnikiem wpływającym na finalną jakość wyników rekonstrukcji. Najbardziej znaną i stosowaną $\mathrm{w}$ praktyce metodą jej wyznaczania jest algorytm obliczania map wrażliwości w oparciu o zależności matematyczno-fizyczne wynikające $\mathrm{z}$ energii pola elektrycznego [7]. Algorytm ten daje w większości przypadków dobre wyniki rekonstrukcji i umożliwia dodatkowo wykonanie procesu iteracyjnej aktualizacji map wrażliwości, dostosowując ich naturę do zmieniającego się wraz $\mathrm{z}$ procesem rekonstrukcji symulowanego rozkładu pola elektrycznego. Do opracowanego systemu pomiarowego autorzy zaprojektowali istotną modyfikację procesu wyznaczania map wrażliwości poprzez uwzględnienie w tym procesie szczegółowego rozkładu pola we wnętrzu czujnika. Opracowany i zaimplementowany tunelowy algorytm wyznaczania macierzy wrażliwości w każdej iteracji procesu rekonstrukcji konstruuje mapy wrażliwości w oparciu o śledzenie powierzchni budowanych wzdłuż linii sił pola elektrycznego [8]. $\mathrm{W}$ artykule tym opisano zrealizowane badania i przedstawiono wyniki działania macierzy wrażliwości wyznaczanych metodą tunelową $\mathrm{W}$ procesie rekonstrukcji obrazów w porównaniu z użyciem tradycyjnych macierzy wrażliwości wyznaczanych 
w oparciu o zależności matematyczno-fizyczne wynikające z równania Laplace'a. Do oceny obrazów zostały przyjęte następujące kryteria:

- znormalizowany średni błąd kwadratowy obrazu (NMSE Normalized Mean Square Error), który pozwala wyznaczyć różnicę pomiędzy zadaną (fantom) i skonstruowaną wartością przenikalności elektrycznej dla danego woksela (obraz) opisany jest zależnością [12],

- współczynnik liniowej korelacji Pearsona, który pozwala ocenić zależność liniową pomiędzy zadaną a skonstruowaną wartością przenikalności elektrycznej dla poszczególnych elementów obrazu - wyrażony wzorem [11, 12].

Aby możliwe było oszacowanie wartości błędów i zastosowanie powyższych kryteriów oceny, proces rekonstrukcji obrazów został przeprowadzony dla zasymulowanego przestrzennego rozkładu przenikalności elektrycznej. W przypadku pomiarów na rzeczywistych obiektach nie jest możliwe opracowanie wiarygodnego referencyjnego modelu rozkładu materiału, który należy podać do zdefiniowanych powyżej kryteriów oceny. Dla potrzeb eksperymentu wykorzystana została liniowa metoda iteracji Landwebera [13]. Za każdym razem przeprowadzonych zostało 400 iteracji przy czym w celu wykazania szybkości zbieżności metody, do prezentacji wyników wybierane były obrazy po $25,100,200$ i 400 iteracjach. Jednocześnie, po każdej iteracji wyznaczane były: błąd średni kwadratowy oraz współczynnik korelacji liniowej. Wyniki przeprowadzonych eksperymentów oraz wyznaczonych kryteriów zostały zaprezentowane na wykresach - rysunki 2 i 3.

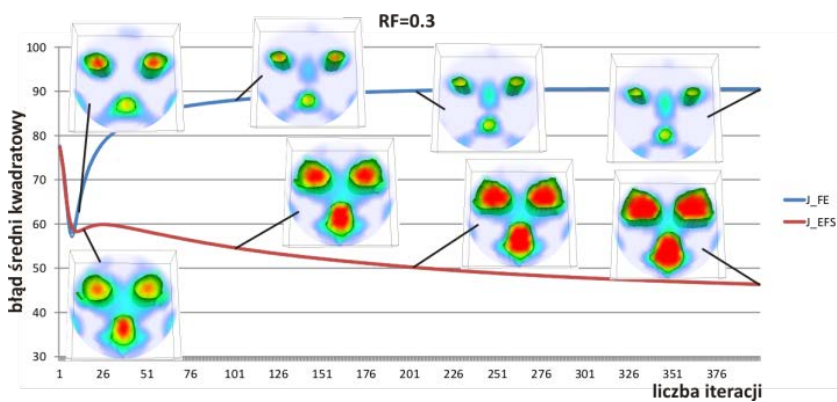

Rys. 2. Wykres przebiegu wartości błędu średniego kwadratowego dla obrazów otrzymanych $w$ wyniku zastosowania metody iteracji Landwebera przy $R F=0.3$ $w$ funkcji liczby iteracji z uzyciem klasycznych (J_FE) i tunelowych (J_EFS) macierzy wrażliwości

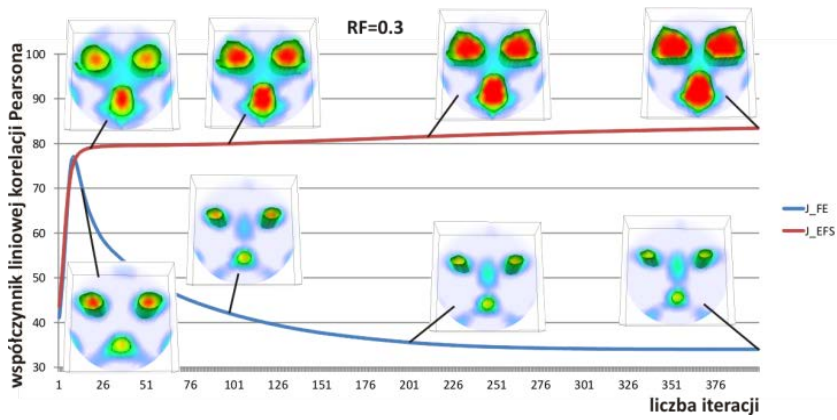

Rys. 3. Wykres przebiegu wartości współczynnika korelacji liniowej Pearsona dla obrazów otrzymanych $w$ wyniku zastosowania metody iteracji Landwebera przy $R F=0.3 w$ funkcji liczby iteracji z uzyciem klasycznych (J_FE) $i$ tunelowych (J_EFS) macierzy wrażliwości

Symbole/skróty na rysunkach oznaczają:

- J_FE - w procesie rekonstrukcji zastosowano klasyczne macierze wrażliwości;

- J_EFS - w procesie rekonstrukcji zastosowano tunelowe macierze wrażliwości;

- RF - (ang. relaxation factor) współczynnik relaksacji (agresywności) metody rekonstrukcji obrazów.

W artykule zdecydowano się przedstawić tylko jeden spośród wielu przeprowadzonych eksperymentów [8]. Na wykresach wykazana została zwiększona szybkość zbieżności w przypadku zastosowania tunelowych macierzy wrażliwości. Cecha ta uwydatnia się bardziej z chwilą zwiększania agresywności procesu rekonstrukcji (zwiększanie współczynnika relaksacji). Warto zauważyć, że dla dużej agresywności procesu w przypadku klasycznych macierzy wrażliwości ostatecznie metoda traci swoją zbieżność, a błędy rekonstrukcji z każdą iteracją powiększają się, co ma niekorzystny wpływ na dalszą analizę obrazów np. metodami logiki rozmytej [5].

\section{Pomiar procentowego udziału faz mieszanin gaz-ciecz}

Algorytm metody wyznaczania procentowego udziału faz w mieszaninie dwufazowej gaz-ciecz w oparciu o system tomografii pojemnościowej bazuje na zidentyfikowanej strukturze przepływu i umożliwia wyznaczanie liczby trójwymiarowych struktur i ich objętości (informacją wejściową dla opracowanej metody są dane pochodzące $\mathrm{z}$ bloku wnioskowania rozmytego [5]). W rozdziale tym, poddany zostanie ocenie metrologicznej wynik działania metody. Zostanie on porównany $\mathrm{z}$ wynikami działania innych metod, jak tradycyjna metoda szybkozamykających się zaworów oraz metoda filmowania przepływu zrealizowana $\mathrm{w}$ oparciu o zbudowane stanowisko do automatycznej analizy przepływu z użyciem kamery CCD [3].

W celu weryfikacji metody wyznaczania udziału faz z wykorzystaniem trójwymiarowego systemu ECT, przeprowadzono złożony eksperyment polegający na jednoczesnej obserwacji przepływu techniką ECT, CCD oraz na pomiarze techniką szybkozamykających się zaworów. W trakcie trwania eksperymentu zapewnione były stałe warunki zasilania rurociągu cieczą oraz gazem. W konsekwencji tego uzyskany został niezmienny charakter przepływu, którego struktury były jednocześnie rejestrowane za pomocą komputerów pracujących $\mathrm{z}$ systemem tomografu oraz $\mathrm{z}$ kamerą $\mathrm{CCD}$, przy zapewnieniu synchronizacji czasowej obu urządzeń (serwer oraz moduły klienckie usługi znaczników czasowych, dodawanych do każdego elementu pomiarowego opisano w [9]). Ponieważ przeważnie długość struktur przepływu (pęcherzy gazowych i następujących po nich rzutów cieczy), które mogą zostać jednoznacznie zidentyfikowane, a co za tym idzie może być poprawnie zmierzony udział faz - jest znacznie większa niż zakres pomiarowy czujnika ECT, jak i obszar skanowania kamery CCD, należało zebrać pewną ilość pomiarów i analizować całą ich sekwencję. Zatem rejestracja pomiarów trwała przynajmniej 90s. To gwarantowało, że w danej sekwencji pomiarów udało się zarejestrować do kilku - nawet najdłuższych, powtarzających się struktur przepływu. Poniżej zamieszczono przykład jednego z wielu zrealizowanych eksperymentów.

Rysunki 4 i 5 przedstawiają zarejestrowane systemem ECT i kamerą CCD przebiegi struktury przepływu rzutowego w sekcji poziomej. Na rysunku tym linią ciągłą zaznaczone zostały udziały fazy ciekłej i gazowej, wyznaczone na podstawie trójwymiarowych obrazów tomograficznych, zrekonstruowanych dla każdej zarejestrowanej ramki pomiarowej ECT (prędkość akwizycji danych to 12 ramek na sekundę; 1 ramka odpowiada 496 pomiarom pojemności). W dalszej kolejności udział fazy ciekłej / gazowej został wyznaczony w oparciu o dane pochodzące $\mathrm{z}$ bloku wnioskowania rozmytego. $\mathrm{Na}$ rysunku 4 widać powtarzające się z dość dużą regularnością cykle rzutów w okresie co $160 \div 170$ tomograficznych ramek pomiarowych. Z kolei linią przerywaną zaznaczono udziały obu faz (ciekłej i gazowej), wyznaczone tym razem na podstawie analizy przeprowadzonej dla całej sekwencji obrazów, zarejestrowanych kamerą CCD (pomiary rejestrowane z prędkością 30 obrazów na sekundę). Sekwencja obrazów CCD (w wyniku synchronizacji czasowej) dokładnie odpowiada pomiarom tomograficznym. 


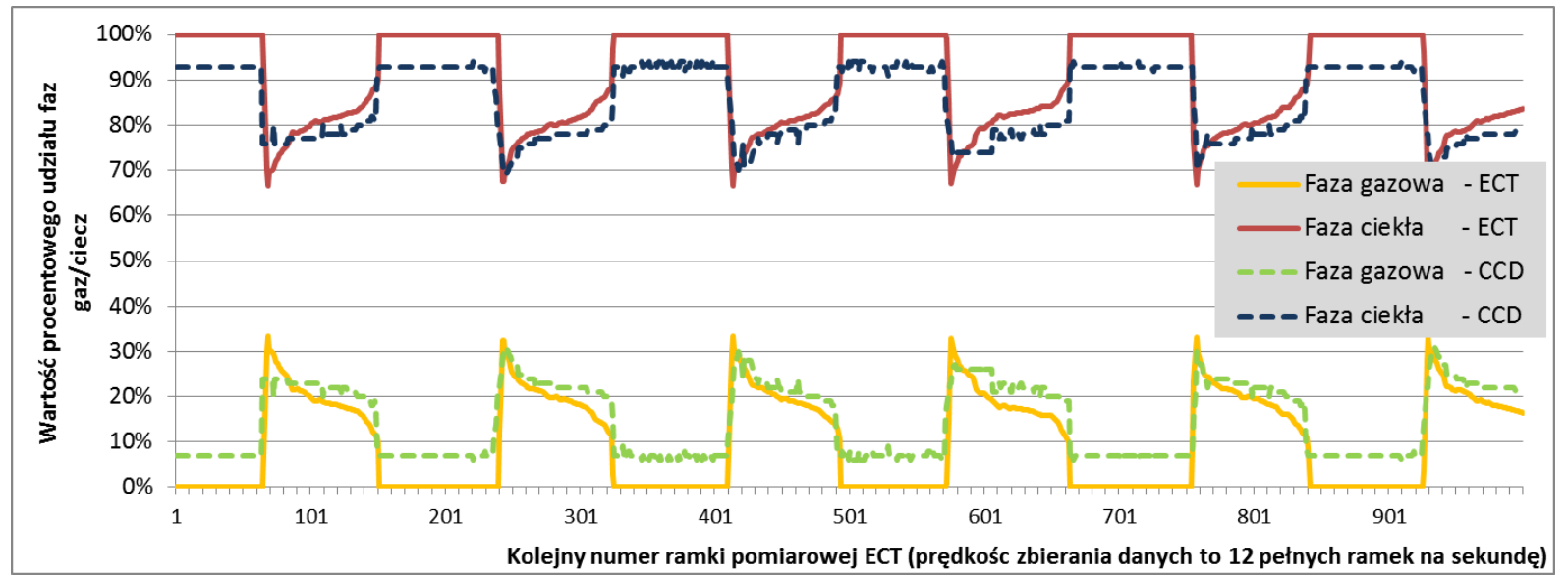

Rys. 4. Zarejestrowane systemem ECT i kamera CCD przebiegi przeplywu rzutowego w sekcji poziomej z zaznaczeniem fazy ciektej i gazowej

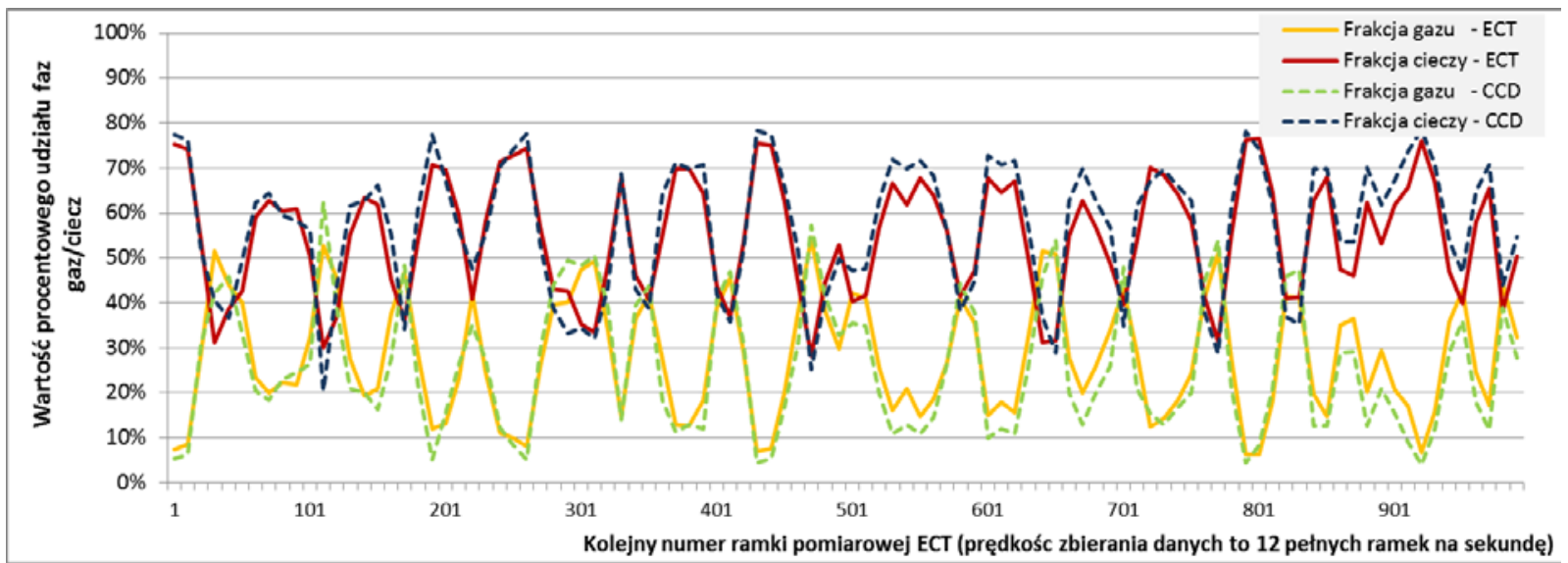

Rys. 5. Zarejestrowane systemem ECT i kamera CCD przebiegi przeplywu pęcherzykowo - rzutowego w sekcji pionowej z zaznaczeniem fazy ciekłej i gazowej

Po zarejestrowaniu wyników opisanych pomiarów - wciąż utrzymując te same stałe warunki przepływu - zastosowano technikę szybkozamykających się zaworów. Warto tu nadmienić, że posiadana w Instytucie Informatyki Stosowanej instalacja badawcza [4] realizuje tę metodę bez konieczności zatrzymywania urządzeń zasilających rurociągi pomiarowe gazem i cieczą. Jest to zapewnione poprzez zamontowanie obejścia (tzw. by-pasu), które otwiera się automatycznie $\mathrm{z}$ chwilą zamknięcia dowolnej sekcji pomiarowej. W wyniku zamknięcia zaworów, w sekcji pomiarowej badanego rurociągu zostaje zatrzymana pewna objętość cieczy (odseparowanej od gazu), której objętość należy wyznaczyć, aby oszacować wartość procentowego udziału faz. W zależności od tego, czy jest to sekcja pionowa, czy pozioma, wykonuje się to na dwa sposoby. W sekcji poziomej należy opróżnić z cieczy odcinek pomiarowy rurociągu zawarty pomiędzy zamkniętymi zaworami i wyznaczyć masę pozyskanej cieczy. Na podstawie znanej gęstości cieczy można wyznaczyć objętość zatrzymanej cieczy, a co za tym idzie jej procentowy udział w przepływie (objętość i masa cieczy wypełniającej całą przestrzeń wewnątrz odcinka pomiarowego rurociągu, musi być wcześniej wyznaczona). W przypadku sekcji pionowej rzecz jest łatwiejsza, bo pomiar realizuje się już bez potrzeby opróżniania sekcji pomiarowej. Wystarczy - po odstaniu się zawartości sekcji pomiarowej, zmierzyć wysokość słupa cieczy. Porównując całkowitą długość odcinka pomiarowego i wysokość cieczy po jej zatrzymaniu i spłynięciu ze ścianek rurociągu, wylicza się procentowy udział faz. Niestety należy mieć na uwadze fakt, iż mimo znacznej długości zamykanej sekcji pomiarowej, wynik działania metody szybko zamykających się zaworów nie jest powtarzalny. Zostanie to wykazane przy okazji prezentacji wyników w dalszej części rozdziału. Problem polega na tym, że metoda daje wynik zależny od momentu, w którym zostaja zamknięte zawory i od związanej z tym liczby uchwyconych rzutów. Może się zdarzyć, że w sekcji pomiarowej zostaną „złapane” przykładowo: podczas pierwszego pomiaru - dwa, a w przypadku drugiego pomiaru - trzy rzuty, w wyniku czego za każdym razem uzyskamy inną wartość udziału faz. Uzyskane średnie wartości pomiarowe udziału faz dla przedstawionego na rysunku 4 eksperymentu wahały się od $88,35 \%$ do $91,41 \%$ udziału fazy ciekłej. Niestety również próba wyliczenia jednej globalnej wartości niepewności pomiarowej dla metody zamykających się zaworów (dla wszystkich sekcji pomiarowych posiadanej instalacji badawczej), zakończyła się niepowodzeniem - z uwagi na fakt, iż metoda ta w przypadku każdej sekcji pomiarowej (pionowa, pozioma, różne średnice) i dla każdej odmiennej struktury przepływu, dostarczała innych wartości odchylenia standardowego wyników, które w żadnym przypadku nie przekraczały $2 \%$.

Rzecz ma się zupełnie inaczej w przypadku pomiarów tomograficznych i kamery CCD. W każdym przypadku czas rejestrowania pomiaru wyniósł 90 sekund. To pozwoliło uśrednić wynik zmierzonego procentowego udziału faz. W przypadku zaprezentowanego eksperymentu - dla badań tomografem wyniósł on $90,01 \%$ udziału cieczy, a dla badań za pomocą kamery CCD $85,14 \%$. Pomiary zostały zestawione w Tabeli 1 . Należy tu również nadmienić, że zarówno za pomocą tomografu jak $\mathrm{i}$ za pomocą kamery $\mathrm{w}$ tym samym przedziale czasowym wykonano kilka jednoczesnych sekwencji pomiarowych, w celu wyznaczenia powtarzalności obu metod. Wyznaczone odchylenie standardowe dla uzyskanych wyników zamieszczono również w Tabeli 1

Podsumowując, technika trójwymiarowej elektrycznej tomografii pojemnościowej sprawdza się również w przypadku pomiaru procentowego udziału faz w przepływie dwufazowym, gwarantując znacznie większą powtarzalność pomiarów, niż tradycyjna technika szybkozamykających się zaworów 
i zapewniając jednocześnie przeprowadzenie bezinwazyjnych pomiarów w czasie rzeczywistym. Podobnie jest w przypadku diagnostyki za pomocą kamery $\mathrm{CCD}$, ale pomimo większej szybkości zbierania danych pomiarowych, kamera obserwuje przepływ tylko z jednej perspektywy (dostarcza obraz jednego przekroju przepływu). Ograniczenie rejestracji przepływu do obrazu dwuwymiarowego, na etapie rzutowania obiektu 2D z obrazu na obiekty trójwymiarowe powoduje powstawanie licznych błędów aproksymacji. Dodatkowo, gdy w analizowanym odcinku przepływu procentowy udział cieczy wynosi $100 \%$, pojawia się (widoczny na wykresie - rysunek 4) problem błędnej analizy obrazu. System wizyjny CCD diagnozuje taki stan jako $93 \%$. Błąd w tym przypadku spowodowany jest dodatkowo specyfiką materiału, z którego wykonana jest sekcja pomiarowa rurociągu oraz jej kolisty kształt. $\mathrm{Na}$ obrazie jasność rury zmniejsza się w kierunku jej górnej i dolnej krawędzi, co przy pewnym poziomie jasności - podczas progowania jest błędnie interpretowane, jako granica międzyfazowa. Efekt ten zademonstrowano na rysunku 6.

Tabela 1. Zmierzony procentowy udzial fazy ciekłej dla przeplywu rzutowego w sekcji poziomej rurociagu o średnicy zewnętrznej fi $=90$

\begin{tabular}{|c|c|}
\hline Metoda pomiaru & $\begin{array}{c}\text { Procentowy udział fazy } \\
\text { ciekłej }\end{array}$ \\
\hline 3D ECT (90 sekundowy eksperyment) & $90,01 \% \pm 0,13 \%$ \\
\hline kamera CCD (90 sekundowy eksperyment) & $85,14 \% \pm 4,74 \%$ \\
\hline $\begin{array}{l}\text { metoda szybkozamykających się zaworów ( } 3 \\
\text { pomiary) }\end{array}$ & $\begin{array}{c}88,35 \% \div 91,41 \% \\
\text { wartość średnia: } 89,88 \%\end{array}$ \\
\hline
\end{tabular}

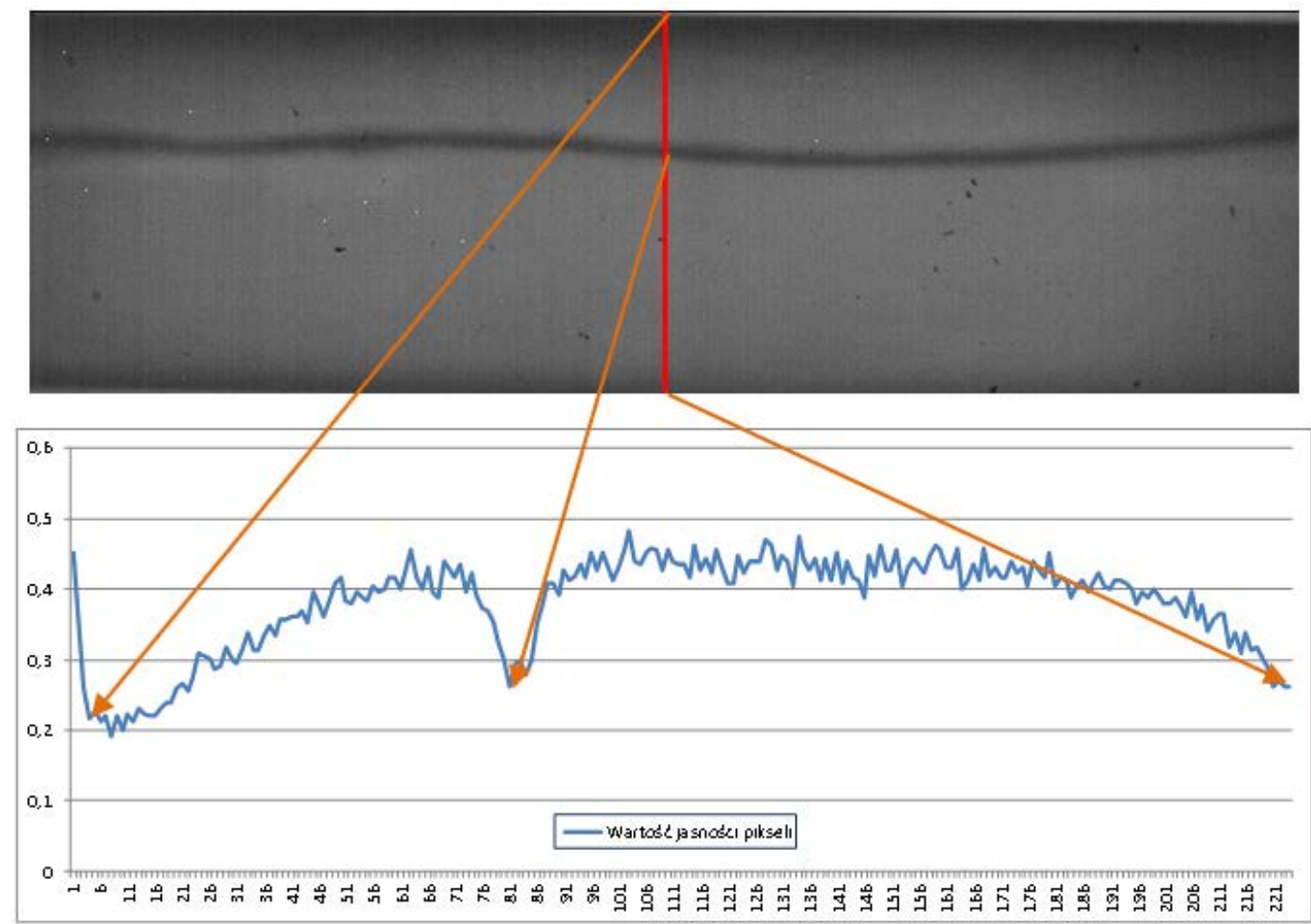

Rys. 6. Wykres wartości jasności punktów obrazu rurociagu zarejestrowanego kamerą CCD

Wzdłuż zaznaczonej na obrazie linii zmierzono poziom jasności punktów i wartości zestawiono na wykresie. Widać, że poziom jasności punktu zaznaczonego strzałką jest podobny do jasności punktów odpowiadających krawędzi rurociągu. Ta cecha powoduje, że projekcja kamery CCD prostopadła do rurociągu, nie pozwala obserwować jego granicznych obszarów do łącznie $14 \%$ objętości.

Opisany spadek wartości jasności punktów na linii rozgraniczającej fazy wymusił zastosowanie algorytmu progowania adaptacyjnego [3], który niestety wprowadza dodatkowe obciążenia. Na niektórych obrazach istniejące szumy są błędnie rozpoznawane jako odrębne małe obiekty i mają one wpływ na wyznaczenie chwilowego położenia granicy międzyfazowej. Niewątpliwe zalety płynące $\mathrm{z}$ analizy przepływów za pomocą dedykowanego systemu wizyjnego, takie jak szybkość i powtarzalność, przewyższają jego wady. Jednakże w porównaniu z algorytmami analizy przepływów opartymi na technice ECT, rozwiązanie to nie jest już tak dokładne i nie daje tak jednoznacznych wyników. Tomograf pojemnościowy dostarcza pełnej przestrzennej informacji pomiarowej, która jest przydatna do zrekonstruowania obrazu całej powierzchni styku obu faz, a co za tym idzie przydatna do jeszcze dokładniejszego pomiaru udziału tych faz.

\section{Podsumowanie}

Opracowany system pomiarowy do identyfikacji struktur i wyznaczania procentowego udziału faz przepływów mieszanin typu gaz-ciecz został poddany ocenie metrologicznej. W celach porównawczych zastosowano inne metody pomiarowe, takie jak: metoda obserwacji przepływu przy pomocy kamery CCD wraz z mechanizmami analizy informacji wizyjnej, metoda wykorzystująca aparaturę do pomiaru prędkości przepływu gazu oraz przemiennik częstotliwości (falownik) do sterowania prędkością obrotową silnika pompy wirowej oraz obserwacje ekspertów. Ocena metrologiczna polegała na wyznaczeniu niepewności pomiarowej opracowanego systemu przy obliczaniu procentowego udziału faz mieszanin gaz-ciecz.

W wyniku przeprowadzonej analizy wykazano dużą przydatność tomograficznego systemu 3D ECT do nieinwazyjnego, szybkiego diagnozowania dynamicznych procesów przepływowych.

Rosnące potrzeby przemysłu w zakresie nieskomplikowanej, relatywnie taniej, nieinwazyjnej i szybkiej metody sterowania procesami przepływów wielofazowych w rurociągach poziomych i pionowych, uzasadniają realizację podjętych tematów badawczych. Możliwość otrzymania obrazu struktury oraz 
identyfikacji rodzaju przepływu dwufazowych mieszanin gazciecz uzyskiwane automatycznie, w systemach czasu rzeczywistego jest bardzo istotna podczas monitorowania instalacji przemysłowych, a także w procesie badań numerycznych w celu weryfikacji wyników. Z kolei ciągłe monitorowanie i diagnozowanie zachodzących procesów przepływowych może stanowić istotną informację o ich przebiegu i ewentualnych nieprawidłowościach oraz umożliwić ich ciągłe automatyczne kontrolowanie i sterowanie. W konsekwencji dane te pozwolą zapobiegać ewentualnym awariom systemów przemysłowych.

\section{Podziękowania}

Prace przedstawione $\mathrm{w}$ ramach niniejszego artykułu były finansowane $\mathrm{z}$ rządowego projektu badawczego nr 4664/B/T02/2010/38.

\section{Literatura}

[1] Banasiak R., Wajman R., Fidos H., Fiderek P., Jaworski T., Nowakowski J., Sankowski D.: System trójwymiarowej tomografii pojemnościowej w zastosowaniu do wyznaczania udziału faz oraz identyfikacji struktur w przepływach mieszanin gaz-ciecz. IAPGOS, 2013, nr 3, 28-31.

[2] Banasiak R., Wajman R., Sankowski D., Soleimani M.: Three-dimensional non-linear inversion of electrical capacitance tomography data using a complete sensor model. Progress In Electromagnetics Research PIER, 100, 2010, pp. 219-234.

[3] Fiderek P., Kucharski J.: A Computer Vision System for On-Line Two-Phase Gas-Liquid Flows Recognition Using Fuzzy Methods. Zeszyty naukowe AGH - Automatyka 15/3 2011, s. 505-519, ISSN: 1429-3447.

[4] Fidos H., Wajman R., Banasiak R., Sowiński J., Sankowski D: Application of electrical capacitance tomography system for non-invasive phases distribution detection in gas-liquid mixtures. Zeszyty naukowe Automatyka 3/2010, AGH, Kraków.

[5] Jaworski T., Fiderek P., Wajman R., Banasiak R.: Identyfikacja przepływu dwufazowego gaz-ciecz oparta na ocenie rozmytej obrazów tomograficznych 3D. IAPGOS, 2013, nr 3, 41-48.

[6] Soleimani M., Wang H., Li Y, Yang W.: A Comparative Study Of Three Dimensional Electrical Capacitance Tomography. International Journal For Information Systems Sciences, 2007, Vol.3, No.2.

[7] Wajman R.: Nowa metoda rekonstrukcji obrazów dla potrzeb pojemnościowej tomografii procesowej. Praca doktorska, Politechnika Łódzka, Łódź, 2006.

[8] Wajman R., Banasiak R.: Nowa metoda tunelowego wyznaczania macierzy wrażliwości dla potrzeb procesu rekonstrukcji obrazów dla trójwymiarowej tomografii pojemnościowej. IAPGOS, 2013, nr 3, 32-37.

[9] Wajman R., Jaworski T., Fiderek P., Banasiak R.: Algorytmu dystrybucji znaczników czasowych dla potrzeb synchronizacji danych z różnych systemów pomiarowych. IAPGOS, 2013, nr 3, 38-40.

[10] Warsito W., Marashdeh Q., Fan L-S. 2007 Electrical Capacitance Volume Tomography. IEEE Sensors Journal, Vol. 7, No. 4, pp. 525-535.

[11] Xie C.G., Huang S.M., Hayes D.G., Gregory I.A., Beck C.M.: Transputer/DSP-based capacitance tomography for real-time imaging and velocity profile measurement of oilfield flow pipelines. Parallel Computing and Transputer Appl., Edts. M.S. Beck u.a., 1994, pp. 123-134.

[12] Yang W.Q., Peng L.: Image reconstruction algorithms for electrical capacitance tomography. Meas. Sci. Technol. 2003, Vol. 14, No. 1, pp. R1R13.

[13] Yang W. Q., Spink D. M., York T. A., McCann H.: An image-reconstruction algorithm based on Landweber's iteration method for electrical capacitance tomography. Meas. Sci. Technol., 10, 1999, pp. 1065-1073.

\section{Dr inż. Radosław Wajman \\ e-mail: rwajman@kis.p.lodz.pl}

Dr inż. Radosław Wajman jest adiunktem w Instytucie Informatyki Stosowanej Politechniki Łódzkiej. Prowadzone badania skupiają się nad zastosowaniem systemów trójwymiarowej tomografii pojemnościowej do nieinwazyjnego monitorowania, diagnozowania oraz automatycznego sterowania pracą przemysłowych instalacji transportu pneumatycznego materiałów sypkich oraz przepływu dwu-fazowego gaz-ciecz.
Dr inż. Henryk Fidos

e-mail: henryk.fidos@p.lodz.pl

Dr inż. Henryk Fidos w roku 1975 ukończył studia w Instytucie Inżynierii Chemicznej Politechniki Łódzkiej. Jest adiunktem w Katedrze Inżynierii Chemicznej Wydziału Inżynierii Procesowej i chrony Środowiska tej uczelni. Specjalność - inżynieria chemiczna i procesowa, mechanika płynów, przepływy wielofazowe, reologia i reometria płynów nienewtonowskich.

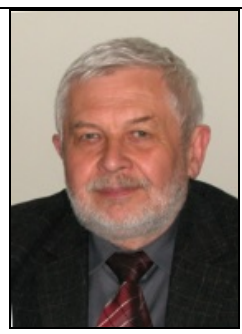

\section{Mgr inż. Pawel Fiderek}

e-mail: p.fiderek@kis.p.lodz.pl

Mgr inż. Paweł Fiderek jest doktorantem w Instytucie Informatyki Stosowanej Politechniki Łódzkiej. W swoich pracach zajmuje się zagadnieniami związanymi $\mathrm{z}$ tomografią komputerową, rozpoznawaniem obrazów oraz sztuczną inteligencją zwłaszcza logiką rozmytą.

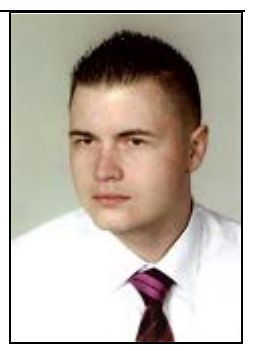

Mgr inż. Tomasz Jaworski

e-mail: tjaworski@kis.p.lodz.pl

Mgr inż. Tomasz Jaworski jest doktorantem w Instytucie Informatyki Stosowanej Politechniki Łódzkiej. W swoich pracach zajmuje się zagadnieniami związanymi z logiką rozmytą oraz przetwarzaniem obrazów.

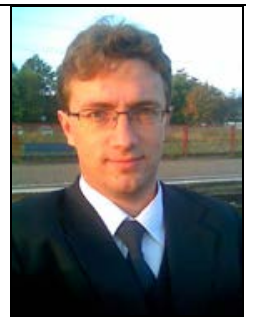

Dr inż. Jacek Nowakowski

e-mail: jacnow@kis.p.lodz.pl

Dr inż. Jacek Nowakowski jest adiunktem w Instytucie Informatyki Stosowanej Politechniki Łódzkiej. Tematyka realizowanych prac naukowych obejmuje zagadnienia dotyczące pomiarów jak również sterowania przepływami wielofazowymi z wykorzystaniem wielomodalnych metod tomograficznych. W ramach grantu Maria Curie DENIDIA prowadził badania na Uniwersytecie w Bergen.

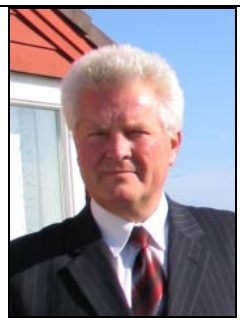

Prof. dr hab. inż. Dominik Sankowski e-mail: dsan@kis.p.lodz.pl

Prof. Sankowski jest dyrektorem Instytutu Informatyki Stosowanej Politechniki Łódzkiej. W ramach prac badawczych zorganizował zespoły naukowe w dziedzinach: przetwarzania, rozpoznawania i analizy obrazów, tomografii procesowej, inżynierii oprogramowania, implementacji technik i metod sztucznej inteligencji, a także automatycznej identyfikacji i regulacji obiektów przemysłowych w systemach czasu rzeczywistego. Aktualna działalność naukowa prof. D. Sankowskiego obejmuje również tematyke związana $\mathrm{z}$ informatyzacja jednostek administracji samorządowej.

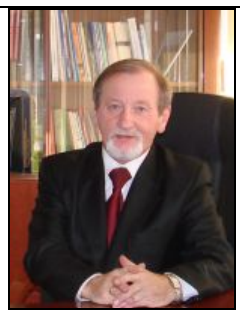

Dr inż. Robert Banasiak

e-mail: robert.banasiak@p.lodz.pl

Dr inż. Robert Banasiak jest adiunktem w Instytucie Informatyki Stosowanej Politechniki Łódzkiej. W swoich pracach zajmuje sie przemysłowymi zastosowaniami elektrycznej tomografii procesowej, a w szczególności problematyką rekonstrukcji obrazów oraz modelowania numerycznego systemów tomografii pojemnościowej. Kierownik grantu 4664/B/T02/2010/38

otrzymano/received: 25.03 .2013

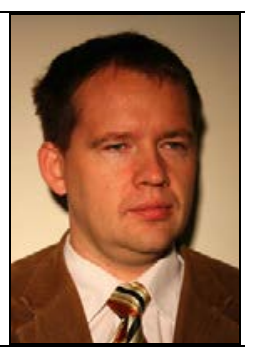

